\title{
Legislative Measures for Preventive Infection Diseases in the Russian Empire Issued During the Tsar Pavel the First
}

\author{
Eduard R. Iskhakov** and Sergey G. Aksenov ${ }^{\mathbf{b}}$ \\ ${ }^{a}$ Ufa Law Institute of the Ministry of Internal Affaires of Russia \\ 2 Muksinova, Ufa, 450103, Russia \\ ${ }^{b}$ Ufa State Aero Technical University \\ 43 Pushkina, Ufa, 450000, Russia
}

Received 22.08.2015, received in revised form 04.09.2015, accepted 30.10.2015

Period of the reforms the Tsar Pavel the First (1796-1801 yy.) continued to produce law regulation for a lot of spheres of life of Russian Empire and such important area as prevention inflection diseases among citizens of Empire. According the legislation the police was the main organization which participated in preventive sanitation and hygienic activity for making health environment in living places. Estimated both the police observing for cleaning town and actions against consuming rotten food and beverages by citizens of town. Some documents itemized the obligations for heads of villages toward hygienic and anti epidemic activity. There were a lot of rules that providing preventive antiinfection actions in military legislation issued by Pavel the First. The military Statutes "About infantry service", "About cavalry service" and Naval Law conclude the obligation for medics of regiment to isolate the infection patients. The special Medical Councils were organized for coordination medical care in regions during period of conducting the Pavel I. Among many obligations of these Councils were such as rules for actions in cases infection diseases, researching infection patients. The main document that regulated activity to protect Russian boarders from infection invasion called "Statute of boarder and port quarantine" issued by 7 July 1800 year.

Keywords: Russian legislation of XVIII century, law regulation about prevention of infection diseases, Tsar Pavel the First, medical legislation.

DOI: 10.17516/1997-1370-2015-8-11-2429-2436.

Research area: history.

\section{Introduction}

Period of the reforms tsar Pavel the First continued to produce law regulation for a lot of spheres of life of Russian Empire. The legislative documents issued during this period included and such important area as prevention inflection diseases among citizens of Empire. In that period the microbial reason of such diseases wasn't known but direct connection between development of the diseases and contacts before to sick, rotten food and sewage were estimated. The preventive measures were not allow to

(C) Siberian Federal University. All rights reserved

* Corresponding author E-mail address: iskhakov1964@mail.ru 
contact with sources of pollution and sick people, make clean in places where people were living. These mentioned above actions were regulated by Pavel's law normative acts.

\section{Materials and methods}

The conducted research was to identify and study the documentary materials from the "Collections the Act of Russian Empire. The first edition. St-Petersburg, 1830". The legislation was investigated from period of the Tsar Pavel the First, who were conducting the Russian Empire from 1796 to 1801 years.

\section{Main part}

A little researches are reflected in modern scientific literature about lawmaking during period by the tsar Pavel the First. Law regulation of different field of society are analyzed, for example "censorship" (Eriashvili N.D., Galuzo V.N. Legal regulation of censorship in board of "Sovereign Imperator" Pavel Petrovich // Vestnik Moskovskogo universiteta MVD Rossii. 2014. № 2. p.23-26.)

or some parts of medicine, for example military medicine (Pechnikova O.G. Codification of medical military law in Russian Empire at the end XVIII century // Yuridicheskaya nauka. 2012, № 2. p. 18-22; Pechnikova O.G. Law regulation military medicine by tsar Pavel the First //Probeli v Rossiiskom zaconodatelstve. 2012. № 2, p. 251-254) or law regulation of medical education (Pechnikova O. G. Law regulation of medical education in Russian Empire at the end of XVIII century // Pravo i obrazovanie. 2012, № 5. p. 162166.). No aspects law regulation of sanitary and hygiene activity in the articles about medical care for citizenships during period of Pavel the First (Pechnikova O.G. Organization and law regulation Russian medicine in regions at the end of XVIII century // Yuridicheskaya nauka. 2012, № 1, p. 13-17). Published researches about law regulation of sanitarian rules in Russian Empire are accompanied period no earlier than end of XIX century (Ivanova J.B. Law regulation veterinarian and sanitarian rules and problems protection fish fund in Russia at the end of XIX and beginning of XX centuries // Sovremennie issledovaniya socialnich problem. 2011. Vol. 7, № 3. p. 108-120) or not show any futures of hygiene and sanitaria (Stochik A.M., Zatravkin S.H., Stochik A.A. Development of state medicine at the second half of XVIII - first half of XX centuries. Report 4. State activity for health-wellbeing, nutrition and work conditions // Problemi socialnoi gigieni, zdravookhraneniya I istorii medicine. 2013, № 4. p. 41-46).

According the legislation the police was the main organization which participated in preventive sanitation and hygienic activity for making health environment in living places. For example, the "Statute of St- Petersburg" issued by 12 September 1798 year had special paragraph where the police should observe the cleaning of town (Collection of acts. V. 25. № 18663. p. 369$382)$.

"The Statute of Moscow" approved by tsar Pavel the First at 17 January 1799 year estimated both the police observing for cleaning town and actions against consuming rotten food and beverages by citizens of town. Special persons (they called vine-keepers) were elected from citizens of Moscow and their obligations were to regulate quality alcohol beverages for sale. Estimated to check the health of brutes in slaughterhouse for Moscow administration because the meat of sick animals were the reasons of toxic-infections among people who used this meat (Collection of acts. V. 25. № 18822. p. 528540).

The Senate Act from 24 August 1799 year paid attention that the physicians didn't make the police requirements - didn't go to villages for fixation cases of inflectional diseases, deaths, 
murders and plague because wasn't money for these trips. Such facts made hygiene situation worsen. Therefore, the Act produced the rules which allowed giving state money for physicians anti-epidemic activity and control money spending (Collection of acts. V. 25. № 19094. p. 767-768).

Concerning the Act from 14 March 1800 year the police horse carts with drivers should take part in cleaning streets and sewerages because the idea for argumentation was that the budgets of towns need in cutting expenses for supporting clearance and these budgets support police therefore the police should make reciprocity (Collection of acts. V. 26. № 19326. p. 66-73).

The document "Statement of Tsar's Family" issued by 5 April 1797 year conducted all villages which belonged Tsar's Family. This document itemized the next obligations for heads of villages toward hygienic and anti epidemic activity: to announce about preventive measures against infection diseases ( $\S 180$ ); to prohibit wetting hemp in places where water to use for drinking because how said in document "people and animal need in healthy water" ( $§ 196)$; to report to authority about new patients with infection diseases immediately ( $§ 198$ ); to clean and collect rubbish and sewage in special places (§ 199); to carry into effect that in local hospitals the separate room should be for patients with infection diseases ( $\$ 204)$ (Collection of acts. V. 24. № 17906. p. 525-535).

The same actions and obligations were included in instruction for German colonies in Saratov region (that issued by 17 September 1800 year) (Collection of acts. V. 26. № 19562. p. 299313).

There were a lot of rules that providing preventive anti-infection actions in military legislation issued by Pavel the First. The military Statutes "About infantry service" (Collection of acts. V.24. № 17 588. p. 26-129) and “About cavalry service" (Collection of acts. V.24. № 17 590. p. 156-212) (issued by 29 November 1796 year) conclude the obligation for medics of regiment to isolate the infection patients.

Some parts of Naval Law (issued by 25 February 1797 year) described necessary prophylactic measures for infection in Navy: obligations for naval doctors to make and support cleaning on the boats (Part 1, Chapter $X$ "About main Naval doctor"); medics should control conditions for treatment patients and to know what they should do in case of infection (Part 2, chapter XIII "About medic"); rules for controlling and making personal hygiene; requirements for cleaning living areas of boats, disinfection; obligation for all naval servants to make oral hygiene; to control the quality of food, deployment and conditions for patients (and linen too) (Chapter V and XI) (Collection of acts. V. 24. № 17833. p. 355-376).

Approved Medical Council Report by Pavel I in 16 July 1799 year estimated the measures for improving preparation medical stuff for Navy and Army (Collection of acts. V. 25. № 19036. p. 721-727). It obligated for medics to reveal the pestis on the boats and ports.

According the Senate Report "About constitution of Ratgauses (Administrations) in all town" issued by 25 February 1801 year the obligation was to provide sanitary and hygiene activity in houses where will be Russian military troops placed (Collection of acts. V. 26. № 19763. p. 542-547).

The special Medical Councils were organized for coordination medical care in regions during period of conducting the Pavel I. It was reflected in Act issued by 19 January 1797 year (Collection of acts. V. 24. № 17 743. p. 287-296). This act directed to change negative situation in Health system in Russian empire in processing medical activity for civic and military people. Medical Councils became the first organizations which 
conducted all medical activity in regions and both civic and military medical care. Among many obligations of these Councils were such as rules for actions in cases infection diseases, researching infection patients. One of the rules was the additional payment to physicians if pesthole appears.

Issued by 1 May 1798 year Act allowed growing Sorochin millet (before the opinion was that it is harmful for health). This Act organized further measures of vaccine prevention against variola (Collection of acts. V. 25. № 18513. p. 233-236).

The big attention paid to having and consuming clear water for people in law acts. The Senate Report approved by tsar by 6 April 1800 year included such statements as analyzing negative impact drinking dirty water to health status of citizens. The result was that if used dirty water that more people died than birth-rate. Detected shortage clear water for using in places where foreigner colonists were living. In summer the water in ponds become low quality and have unpleasant smell (Collection of acts. V. 26. № 19372. p.115-128).

The Pavel I checked and controlled the conditions for patients personally. For example he attended Moscow General Hospital. The result and proposals of his attending were reflected in Act issued by 2 April 1797 year. The content of this act showed that the Tsar revealed very small space in places for deployment of patients inside the Hospital and narrowness in the rooms. The decisions were to check all hospitals in Russia and to estimate the presence separate rooms for infection patients and make big attention to cleanliness. The Act gave the order to analyze all information about conditions for patients at the hospitals and prepare recommendations for improving activity of hospitals (Collection of acts. V. 24. № 17902. p. 522).
The main document that regulated activity to protect Russian boarders from infection invasion called "Statute of boarder and port quarantine" issued by 7 July 1800 year. The statute had some features. At the beginning of Act the opinion was underlined that country needs in solving such question as organization and functioning the quarantines because its need for protect boarder against pestis invasion. Itemized the pre-requisitions for producing this document: 1) former document not enough for safety particularly from Black Sea, Austrian and Ottoman Empires; 2) it was necessary to pay attention to human psychology because it has special behavior. The special behavior is if something prohibited in making in one way the people will look for and make another way for passing prohibition.

The methods of disinfection for boats (known in that period) were mentioned in statute: 1) burn the boats with goods; 2) remove the boats from Russian boarders.The results of these methods are analyzed: will not benefits and will future shortage of goods in Russia.

Another negative outcomes of such methods are considered because it is connected with psychology of merchants. Existing prohibitions for transportation pestiferous goods forced searching another way for destination inside Russia and it will be the reasons for negative consequences for health of people and damaging Russian Empire.

In our opinion the very essential part of document is the part about financing quarantines activity. The Statute declared the importance of increasing number of stuff, providing good salary, making rules for financial process. Estimated additional money payment for "good service for state", it depended on length of service (minimum 10 years without mistakes), compensation to family if death during abilities making. It may 
consider how supporting anti-corruption behavior the officials.

The part 1 "About Quarantine house" stated that construction of functioned outposts is the best way to protect Russia from infection invasion like pestis. It listed the conditions and requirements for places and wind directions where will be outposts situated.

The Part II established the positions for stuff of quarantine and moral, ethical and professional requirements for them and anticorruption features of stuff. There were rules concerning nutrition for people who staying in outposts, order, agenda in quarantine outposts for boats, loads, documents. The $\S 48$ allowed to use for working the condemners in a very dangerous places in outposts.

The part 6 of Statute described list of common and particular obligations for stuff position as "commissar" (it means special person who manages activity of quarantine) for providing hygiene and epidemic regime in outposts: providing alimentation and controlling good quality of food, controlling cleanness, duties, special regime, deployment of patients and their isolation, special regime during funeral of deceased from infection, special conditions for patients: beds, changeable linen, twice a day investigation of infection patients.

The part 7 "About preventive organizations" elucidated the reasons of plaque, its contamination and necessarily to estimate quarantine for merchants and no contacts between them during staying in quarantines, underlined the pestiferous Turkish goods. Listed methods of disinfection and keeping miscellaneous goods that pestiferous.

The part 8 "Preventive measures for passing through the boarder people, goods and clothes" explicated the order and rules of observing and taking travelers and merchants, rules for disinfection cattle and mail packs.
The Part 9 included the rules for taking for boats which arrived from suspicious places of pesthole, precautions in disembarkation of goods.

The part 10 "Precautions if infection sick is on the boat" provided the list of actions toward sick, his/her bed, clothes ("with stones to drop in sea"), disinfection places where lied the sick (Collection of acts. V.26. № 19476. p.198-225).

There was the immediate reaction the authority of Russia when the threaten of infection invasion. The Act "Precautions because the infection diseases appeared in England" as urgent way issued by 8 December 1800 year. This Act constituted that the contagious diseases are in England and therefore preventive measures should be activated particularly concerning describing in "Statute of boarder and port quarantine" (Collection of acts. V. 26. № 19679. p. 425).

We couldn't make compare Russian actions with existing measures against inflectional diseases in other countries near Russian boarder or in Europe. The results were found by our concerned more late period (beginning and middle of XIX century) (Gábor Palló Rescue and cordon sanitaire: The Rockefeller Foundation in Hungarian public health // Studies in History and Philosophy of Science Part C: Studies in History and Philosophy of Biological and Biomedical Sciences, Volume 31, Issue 3, September 2000, Pages 433-445; Michael Worboys Was there a Bacteriological Revolution in late nineteenth-century medicine? // Studies in History and Philosophy of Science Part C: Studies in History and Philosophy of Biological and Biomedical Sciences, Volume 38, Issue 1,March 2007, Pages 20-42.; Stephen W. Speake. Infectious milk: issues of pathogenic certainty within ideational regimes and their biopolitical implications // 
Studies in History and Philosophy of Science Part C: Studies in History and Philosophy of Biological and Biomedical Sciences, Volume 42, Issue 4,December 2011, Pages 530-541.; Marcel Chahrour A civilizing mission'? Austrian medicine and the reform of medical structures in the Ottoman Empire, 1838-1850 // Studies in History and Philosophy of Science Part C: Studies in History and Philosophy of Biological and Biomedical Sciences, Volume 38, Issue 4,December 2007, Pages 687-705.; Matthew Smallman-Raynor, Andrew D. Cliff The geographical spread of cholera in the Crimean War: epidemic transmission in the camp systems of the British Army of the East, 185455 Journal of Historical Geography, Volume 30, Issue 1, January 2004, Pages 32-69), or more late period (Sherry Olson, Kevin Henry, Michèle Jomphe, Kevin Schwartzman, Paul Brassard Tracking tuberculosis in the past: the use of genealogical evidence // Journal of Historical Geography, Volume 36, Issue 3, July 2010, Pages 327-341), or considered dissemination of inflectional diseases from philosophy point of view (Anya Plutynski Philosophy of epidemiology Studies in History and Philosophy of Science Part C: Studies in History and Philosophy of Biological and Biomedical Sciences, Volume 46, June
2014, Pages 107-111). Besides, many aspects of preventive of dissemination of infections in articles about medical care at the end of XVIII didn't discussed (Spary E.C. Introduction: Centre and periphery in the eighteenth-century Habsburg 'medical empire' // Studies in History and Philosophy of Science Part C: Studies in History and Philosophy of Biological and Biomedical Sciences, Volume 43, Issue 3, September 2012, Pages 684-690), and also the questions didn't touch about legal aspects fighting and prophylactic inflectional diseases (Andrews J. History of Medicine: Health, Medicine and Disease in Eighteenth Century // Journal for Eighteenth-Century Studies. Vol.34. No.4. 2011. P. 503-515).

\section{Conclusion}

There was law regulation of hygiene and epidemic activity against invasion infection through boarders and its disseminations inside Russia issued during conducting the Pavel I. The quarantine actions were developed. The legislation for using within Russian Empire included: the rules concerning the providing cleanness in citizens and places army deployment, drinking pure water, beverages and food, rules how acts because infection diseases appeared.

\section{References}

Andrews J. (2011). History of Medicine: Health, Medicine and Disease in Eighteenth Century. Journal for Eighteenth-Century Studies, 34(4), 503-515.

Collection of the Act of Russian Empire. The first edition. St-Petersburg, 1830.

Chahrour M. (2007) A civilizing mission'? Austrian medicine and the reform of medical structures in the Ottoman Empire, 1838-1850. Studies in History and Philosophy of Science Part C: Studies in History and Philosophy of Biological and Biomedical Sciences, 38(4), 687-705.

Eriashvili N.D., Galuzo V.N. (2014). Pravovoe regulirovanie tsenzury v pravlenie «Gosudaria Imperatora» Pavla Petrovicha. Vestnik Moskovskogo universiteta MVD Rossii, (2), 23-26.

Gábor P. (2000). Rescue and cordon sanitaire: The Rockefeller Foundation in Hungarian public health. Studies in History and Philosophy of Science Part C: Studies in History and Philosophy of Biological and Biomedical Sciences, 31(3), 433-445. 
Ivanova J.B. (2011). Law regulation veterinarian and sanitarian rules and problems protection fish fund in Russia at the end of XIX and beginning of XX centuries. Sovremennye issledovaniya socialnykh problem, 7(3), 108-120.

Olson Sh., Henry K., Jomphe M., Schwartzman K., Brassard P. (2010). Tracking tuberculosis in the past: the use of genealogical evidence. Journal of Historical Geography, 36(3), 327-341.

Pechnikova O.G. (2012a) Codification of medical military law in Russian Empire at the end XVIII century. Yuridicheskaya nauka, (2), 18-22.

Pechnikova O.G. (2012b). Law regulation military medicine by tsar Pavel the First. Probely $v$ Rossiiskom zaconodatelstve, (2), 251-254.

Pechnikova O. G. (2012c). Law regulation of medical education in Russian Empire at the end of XVIII century. Pravo i obrazovanie, (5), 162-166.

Pechnikova O.G. (2012d). Organization and law regulation Russian medicine in regions at the end of XVIII century. Yuridicheskaya nauka, (1), 13-17.

Plutynski A. (2014). Philosophy of epidemiology. Studies in History and Philosophy of Science Part C: Studies in History and Philosophy of Biological and Biomedical Sciences, 46, 107-111.

Smallman-Raynor M., Cliff A. D. (2004). The geographical spread of cholera in the Crimean War: epidemic transmission in the camp systems of the British Army of the East, 1854-55. Journal of Historical Geography, 30(1), 32-69.

Spary E.C. (2012). Introduction: Centre and periphery in the eighteenth-century Habsburg 'medical empire'. Studies in History and Philosophy of Science Part C: Studies in History and Philosophy of Biological and Biomedical Sciences, 43(3), 684-690.

Stephen W. (2011) Speake. Infectious milk: issues of pathogenic certainty within ideational regimes and their biopolitical implications. Studies in History and Philosophy of Science Part C: Studies in History and Philosophy of Biological and Biomedical Sciences, 42(4), 530-541.

Stochik A.M., Zatravkin S.H., Stochik A.A. (2013). Development of state medicine at the second half of XVIII - first half of XX centuries. Report 4. State activity for health-wellbeing, nutrition and work conditions. Problemi socialnoi gigieni, zdravookhraneniya I istorii medicine, (4), 41-46.

Worboys M. (2007). Was there a Bacteriological Revolution in late nineteenth-century medicine? Studies in History and Philosophy of Science Part C: Studies in History and Philosophy of Biological and Biomedical Sciences, 38(1), 20-42. 


\title{
К вопросу о законодательных мерах
}

\section{по предупреждению инфекционных заболеваний}

\section{в Российской империи}

\section{(в период правления Павла I)}

\author{
Э.Р. Исхаков ${ }^{\mathrm{a}}$, С. Г. Аксенов ${ }^{\mathbf{0}}$ \\ ${ }^{a}$ Уфимский юридический институт МВД России \\ Россия, 450103, Уфа, Муксинова, 2

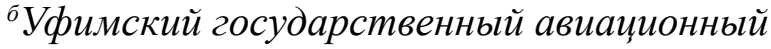 \\ технический университет \\ Россия, 450000, Уфа, ул. Пушкина, 43
}

\footnotetext{
В статье приводятся нормативно-правовые документы, изданные во время правления иаря Павла Первого, которые имели противоэпидемическую и санитарно-гигиеническую направленность. Акты регулировали профилактические мероприятия по недопущению заноса инфекиионных заболеваний из-за границы, возникновению и распространению их среди гражданского населения, а также в российских войсках и военных флотах.

Ключевые слова: российское законодательство ХVIII века, правовое регулирование профилактики инфекционных заболеваний, царь Павел Первый, медицинское законодательство.

Научная специальность: 07.00.00 - исторические науки.
} 